\title{
MULTI-CRITERIA CLASSIFICATION AND SEGMENTATION ANALYSIS OF HIGH-TECHNOLOGY MANUFACTURING IN WARSAW
}

\author{
Agnieszka SKALA*, Katarzyna ROSTEK** \\ *Warsaw University of Technology, Faculty of Transport \\ e-mail: askala@wt.pw.edu.pl \\ **Warsaw University of Technology, Faculty of Management \\ e-mail:k.rostek@wz.pw.edu.pl
}

\begin{abstract}
The goals of this research were to identify and describe the HTM sector in Warsaw and to indicate which part had the highest market potential. The article presents the results of a multidimensional and multi-criteria classification analysis. The segmentation analysis performed made it possible to extract the most distinguished subgroups of the HT population. Particular attention was paid to the HTM exporters (HTME) group, which was identified as the most promising group of companies in the HT sector. The description of the HTME subgroup paves the way for further research with the criteria of differentiating and strengthening internal development in the HT population.
\end{abstract}

Keywords: entrepreneurship, high-technology, exporters, manufacturing, differentiating criteria, classification analysis, segmentation analysis.

\section{Introduction}

The analysis presented in this paper on the hightechnology manufacturing (HTM) sector in Warsaw was undertaken as a part of the "Warsaw Entrepreneurship Forum"1 project.

The basic classification of the high-technology (HT) industry, in terms of its technology level, divides it into four categories: high technology, medium-high technology, medium-low technology, and low technology [22]. The HT sector is important to the economy and has a significant impact on the nature and pace of economic growth in developed countries.

Business activity in the area of high technology ${ }^{2}$ refers to the areas of manufacture, services, and products, which are highly science-intensive, that is, they are characterized by a high level of "science intensity." The latter manifests itself in the high values of two parameters: R\&D intensity (calculated as the ratio of expenditure on $R \& D$ in relation to sales

\footnotetext{
${ }^{1}$ The European Project is entitled "Stoleczne Forum Przedsiębiorczości" (Warsaw Entrepreneurship Forum) - "Development, promotion and pilot implementation of new methods of collaboration between the Warsaw authorities and businesses in order to ensure efficient management of economic change." Cofounded by the EU under the European Social Fund, agreement No. UDA-POKL.08.01.02-14-137/11.

${ }^{2}$ In this article, the expressions "high-tech" and "high technology" are used synonymously, as well as represented by the abbreviation HT for the whole sector.
}

achieved by the company called) and the presence of scientists and engineers in the staff $[7,9,15,16$, 19, and 20].

A major distinction splits the HT sector into two groups: manufacturers and service providers. Hightechnology Knowledge-Intensive Services (HT_KIS) are as follows: motion picture, video, and television production, sound recording, music publishing, programming and broadcasting, telecommunication, computer programming, consultancy and related services, information services, and, finally, scientific research and development. However, the HT service group is not the subject of this study. This study focuses exclusively on the HT manufacturing (HTM) branches, which are electronics, pharmaceuticals, aviation, and spacecraft.

Statistics confirm a strong and growing position of the HT sector in the overall market, as well as in industrial production. Its share in added value of the manufacturing industry ${ }^{3}$ in the European Union (EU)

\footnotetext{
${ }^{3}$ Value added at factor cost is the gross income from operating activities after adjusting for operating subsidies and indirect taxes. It can be calculated from turnover and capitalized production, plus other operating income, plus or minus the changes in stocks, minus the purchases of goods and services, minus other taxes on products that are linked to turnover, but not deductible, minus the duties and taxes linked to production (source: Eurostat).
} 
in 2010 was $12 \%$. Data from the years 2005 to $2013^{4}$ indicate that while the global index of growth in industrial production in this period remained at the same level, the analogous rate for branches of the HT industry increased by $26 \%$ [11]. The clear decrease in production during the peak period of the economic crisis, which fell between Q1_2008 and Q2_2009, affected HT production much less than other branches (decreased by 10 percentage points, and not by 20 percentage points, as in the case of the whole industry). The growth in sold production in the HT sector is primarily due to large increases in production in the pharmaceutical sector $(\sim 3.2 \%$ annually) and, above all, in the aviation and space industry sectors ( $\sim 5 \%$ annually).

What is interesting is that Eurostat reports the average annual production growth rate in the groups of industry specified in terms of technological level (low, medium-low, medium-high, and high) disaggregated into particular member states. In this list, Poland fares very well, registering the second-best result (after Estonia) in the HT sector: $+14.5 \%$ annually in the period 2005-2011 (the EU average is $3.3 \%$ ). This will not change the fact that Poland's share in the EU production of HT goods does not exceed $2 \%$ (1.7\% in 2010), and reaches only $6.7 \%$ (2013) in export. Whereas, the average for EU-27 is $15.3 \%$, and leaders (including the aforementioned Estonia) achieve the value of this share in the $15 \%$ $20 \%$ range [11].

Although statistics is collated and research is conducted on the HT sector, the definition of this term continues to be rather ambiguous $[1,8,9,20,28]$. The boundaries between sectors in the economy gradually disappear in the process of "industry convergence," which also affects one of the most important HT industries: pharmaceuticals [6].

There is an ongoing debate on the question of the criteria under which companies can or cannot be considered as belonging to the HT industry [28]. As many as 19 definitions of tech. company have counted Grinstein and Goldman analyzing literature only until 2000 [9, p.126]. Owing to this ambiguity, companies in the HT sector tend to be considered a rather homogeneous group gathering similar enti-

\footnotetext{
${ }^{4}$ It specifically concerns the period between the first quarter
} of 2005 and the third quarter of 2013. ties, when in fact it can be very varied and uneven in terms of market potential and development stage.

An important consideration here is the accelerating trend towards the reindustrialization of cities, which has also reached the capital of Poland [12, 31]. The "purity" of technologies that come under the "high-technology" heading has a beneficial effect on the increase of employment rates among the most highly skilled workforce, and especially amongst young people. This is a strong case for an active reindustrialization policy with respect to the development of the HT sector in metropolitan areas.

An incentive here is the fact that the sector already has a significant presence in Warsaw, which is particularly visible in the central districts of the city. All this creates a chance of dynamic development in this direction for other city districts, and provides an opportunity for those enterprises that see their opportunity for market expansion in the revival of production (rather than in the services sector only).

The latest publications focus on this sector of the economy as the subject and object of a new wave of industrial revolution leading to the popularization of the Industry 4.0 environment [13, 14]. Small and medium HT entrepreneurs will create quick and geographically proximate solutions, which will be immediately used by large companies to produce a short series of customized products ideally suited to individual needs. Therefore, the first objective of the present research was:

\section{O1: To classify the characteristics of the Warsaw population of HTM companies.}

Given the above, the scope of this study is to explore the criteria that identify the HT sector companies that have a positive impact on the economy. This is reflected in the layout of this article, which begins with a review of literature on the characteristics of HT producers. Then, the methods and tools used in the study are described, as well as the results of research and its discussion are explained. In conclusion, further research directions are indicated. 
Features distinguishing HT manufacturers - literature and knowledge perspectives

Classification of manufacturers into the HT industry may be done based on affiliation to a sector of the economy (sectorial approach) or goods produced by them (product approach) [22, 27]. According to the sectorial approach, the HT production category now includes companies that declare their main activity in any of these three kinds of production: pharmaceuticals, electronics, and air and spacecraft. On the other hand, in the product approach, there are nine groups of goods that are a result of the production processes: aerospace computers and office machines, electronics/ telecommunications, pharmacy, scientific instruments, electrical machinery, chemistry, non-electrical machinery, and armament.

Factors characterizing the HT sector are discussed in the literature. Among them, the high level of the innovativeness of processes or final products is highlighted as well as the fact of stable, well-paid job creation for highly skilled workforce $[1,2,21,29$, and 30]. These are highly productive and competitive companies [2, 20, 21, 29, and 32] that raise the technological level in the entire economy $[18,26]$ usually having extremely short product lifecycles [28] and cooperating with science. The high market and investment risk in the sector is compensated by a potential profit from successful investment and a long-term benefit for the market and economy [20]. Moreover, irrespective of the selection criteria used, HT companies provide an excellent space for research on the latest trends in technology, management, and marketing $[25,33]$.

While searching for the criteria that distinguish HT companies, a high propensity to export appears often in the research results $[4,5]$. A popular argument is that firms that export grow faster and stronger. Studies confirm the positive relationship between export activity and high productivity $[10,17]$ as well as the share of employees with higher education in total employment and the expenditure level on R\&D [3]. All three features - high productivity, raised share of employees with higher education, and a high level of R\&D expenditure - are characteristic of HT companies. Hence, the second objective of the present research was::

O2: To verify the hypothesis that export is a strong and important distinguishing criterion in the HTM companies in Warsaw.

The realization of this goal required the development of the characteristics of the research group, which was Warsaw's HTM sector. This analysis was also used to search for new, atypical, and specific characteristics distinguishing leading companies in the study group. The result is a characterization of the HT Warsaw sector with particular emphasis on the role and importance of exports.

\section{$3 \quad$ Research methodology}

Identification and descriptive characteristics of the HTM population in Warsaw is addressed in the fourth stage of the research, which has been in progress from 2013 to 2015 . Table 1 presents the most important elements of the successive stages of the research: aims, data sources, methodology used, and main findings.

The initial purpose of the research was to provide material for the description of the Warsaw HT population. However, the study revealed a major difficulty in identifying HT entities. Therefore, the first step was to identify HT companies from among other business entities registered in Warsaw. The basic criterion for qualifying HT companies, which is based on the PKD declared by the companies, was recognized as not reliable. Therefore, the need arose to define a new method that would provide an unequivocal answer to the question that which companies should and should not be regarded as HT. A hybrid method was proposed, which combined the data from GUS, ZUS, and information available online [27]. 
Table 1. Research method used on the HTM population in Warsaw

(source: authors' research)

\begin{tabular}{|c|c|c|c|c|c|}
\hline $\begin{array}{l}\text { Research } \\
\text { stage }\end{array}$ & $\begin{array}{l}\text { Research } \\
\operatorname{aim}(\mathbf{s})\end{array}$ & $\begin{array}{c}\text { Analysis } \\
\text { methodology }\end{array}$ & Data source(s) & Data type & Research description \\
\hline \multirow{3}{*}{1} & \multirow{3}{*}{$\begin{array}{l}\text { Identification } \\
\text { of HT sector }\end{array}$} & \multirow{3}{*}{$\begin{array}{l}\text { quantitative / } \\
\text { qualitative }\end{array}$} & $\begin{array}{l}\text { GUS } \\
(\text { REGON) }\end{array}$ & PKD sector & $\begin{array}{l}\text { Use of sectoral criterion, } \\
1363 \text { potentially HT entities iden- } \\
\text { tified }\end{array}$ \\
\hline & & & ZUS & $\begin{array}{l}\text { Activity } \\
\text { indicator }\end{array}$ & $\begin{array}{l}\text { Verification of the activity, } \\
566 \text { entities left }\end{array}$ \\
\hline & & & $\begin{array}{l}\text { Company's } \\
\text { website }\end{array}$ & $\begin{array}{l}\text { Offer } \\
\text { (product) }\end{array}$ & $\begin{array}{l}\text { Verification of the correctness } \\
\text { of the sectoral criterion, } \\
137 \text { companies identified as HT }\end{array}$ \\
\hline \multirow[b]{2}{*}{2} & \multirow[b]{2}{*}{$\begin{array}{l}\text { Characteristics } \\
\text { of HT sector }\end{array}$} & \multirow[b]{2}{*}{$\begin{array}{l}\text { quantitative / } \\
\text { qualitative }\end{array}$} & $\begin{array}{l}\text { GUS } \\
(\text { REGON) }\end{array}$ & 8 attributes & $\begin{array}{l}\text { The basic profile of HT sector: } \\
\text { type of activity, legal form, type } \\
\text { of ownership, employment (size } \\
\text { ranges at the moment of registra- } \\
\text { tion) }\end{array}$ \\
\hline & & & $\begin{array}{l}\text { Company's } \\
\text { website }\end{array}$ & 11 attributes & $\begin{array}{l}\text { In-depth analyses of the sector, } \\
\text { type of activity and transactions, } \\
\text { cooperation with science, } \\
\text { employment, self-assessment } \\
\text { if innovativeness, foreign } \\
\text { language of the website, } \\
\text { import or export activities }\end{array}$ \\
\hline 3 & $\begin{array}{l}\text { Features } \\
\text { distinguishing } \\
\text { HT sector }\end{array}$ & $\begin{array}{l}\text { Segmentation } \\
\text { analysis: } \\
\text { Ward's clus- } \\
\text { tering and } \\
\text { Self- } \\
\text { Organizing } \\
\text { Map (SOM } \\
\text { Kohonen) }\end{array}$ & \multicolumn{2}{|l|}{ All data collected } & $\begin{array}{l}\text { The strongest criteria differentiat- } \\
\text { ing Warsaw HT companies } \\
\text { (in the order of importance): } \\
\text { - export activity, } \\
\text { - scientific activity, } \\
\text { - searching for and employing } \\
\text { new staff, } \\
\text { - share of foreign capital in the } \\
\text { form of ownership. }\end{array}$ \\
\hline \multirow{3}{*}{4} & \multirow{3}{*}{$\begin{array}{l}\text { Characteristics } \\
\text { of HT export- } \\
\text { ers (HTME) }\end{array}$} & \multirow{3}{*}{$\begin{array}{l}\text { quantitative / } \\
\text { qualitative }\end{array}$} & \multicolumn{2}{|l|}{ All data collected } & \multirow{3}{*}{$\begin{array}{l}\text { Characteristics of the HTME } \\
\text { group }\end{array}$} \\
\hline & & & CAAC & 10 attributes & \\
\hline & & & $\begin{array}{l}\text { Company's } \\
\text { website }\end{array}$ & 2 attributes & \\
\hline
\end{tabular}

Abbreviations: PKD: Polish Classification of (business) Activity (NACE codes), GUS: National Office of Statistics, ZUS: Social Insurance Institution, CAAC: Analytical Centre of Customs Office. 
Table 2. Classification of attributes of HT and HTME within all datasets (source: authors' research)

\begin{tabular}{|c|c|c|c|}
\hline \multirow{2}{*}{$\begin{array}{c}\text { Used at the \# } \\
\text { of research } \\
\text { stage } \\
\end{array}$} & \multicolumn{2}{|r|}{ Attribute } & \multirow{2}{*}{ Data source } \\
\hline & Name & Description & \\
\hline \multirow{2}{*}{$1,2,3,4$} & REGON & REGON number; set identifier & GUS \\
\hline & HiTech & PKD group & GUS \\
\hline \multirow{3}{*}{$2,3,4$} & FP & Specific legal form & GUS \\
\hline & $\mathrm{FZ} \_1$ & Share of foreign capital & GUS \\
\hline & LPRAC & Number of employees (ranges) & GUS \\
\hline $1,2,3,4$ & WA & Activity Indicator & ZUS \\
\hline \multirow{11}{*}{$2,3,4$} & $\mathrm{~B} 2 \mathrm{~B}$ & Type of sale: B2B & website_1study \\
\hline & $\mathrm{B} 2 \mathrm{C}$ & Type of sale: B2C & website_1study \\
\hline & CERT & Certificates & website_1study \\
\hline & AKTYW & Assessment of activity & website_1study \\
\hline & LANG & Website in foreign language & website_1study \\
\hline & NAUKA & Cooperation with science centers & website_1study \\
\hline & PATENT & Patents & website_1study \\
\hline & PRACOW & Searching for new employees & website_1study \\
\hline & SOCIAL & Social networking service account & website_1study \\
\hline & EKSPORT & Export activity & website_1study \\
\hline & INNO & Self-assessment of innovative nature & website_1study \\
\hline \multirow{11}{*}{4} & EKSPORT_12 & Range of export value in 2012 & CAAC \\
\hline & Eksporty_Kraj & Main destination of export in 2012 (country) & CAAC \\
\hline & E_Kraj/E \% & $\%$ of the export value to the main destination & CAAC \\
\hline & E_EU/E \% & Destination to EU as \% of total exports & CAAC \\
\hline & Liczba_KrajEU & Number of exports destinations in EU (countries) & CAAC \\
\hline & Liczba_KrajPoza & $\begin{array}{l}\text { Number of exports destinations outside EU (coun- } \\
\text { tries) }\end{array}$ & CAAC \\
\hline & Liczba_Kraj & Number of all exports destinations & CAAC \\
\hline & GrupaHT & Group of high-tech products exported & CAAC \\
\hline & E_HT/E \% & $\begin{array}{l}\text { High-tech products export value as \% of total } \\
\text { export value }\end{array}$ & CAAC \\
\hline & Research-oriented & $\begin{array}{l}\text { Based on research center, having laboratory, es- } \\
\text { tablished by scientists etc. }\end{array}$ & website_2study \\
\hline & Successor & $\begin{array}{l}\text { The company is continuing activity of former } \\
\text { state institution or company }\end{array}$ & website_2study \\
\hline
\end{tabular}

Abbreviations: PKD: Polish Classification of (business) Activity (NACE codes), GUS: National Office of Statistics, ZUS: Social Insurance Institution, CAAC: Analytical Centre of Customs Office, website_2stud:y the second round of the screening of the companies' websites. 
Table 3. HTME group classified by export value range in 2012

(source: authors' research)

\begin{tabular}{|c|c|c|}
\hline Symbol of the value range & $\begin{array}{c}\text { Range of the export value in 2012 r. } \\
\text { (million PLN) }\end{array}$ & HTME group \\
\hline Z & 0 & inactive \\
\hline A & $<1$ & micro \\
\hline B & $1-2$ & \multirow{2}{*}{ small } \\
\hline C & $2-4$ & \multirow{2}{*}{ medium } \\
\hline D & $4-8$ & \\
\hline E & $8-16$ & \multirow{2}{*}{ large } \\
\hline F & $16-32$ & \\
\hline G & $32-64$ & \\
\hline H & $64-128$ & \\
\hline I & $128-256$ & \\
\hline J & $>256$ & \\
\hline
\end{tabular}

The second step aimed at characterizing the HT sector (137 entities) using analytical methods enriched by the data obtained from companies' websites [23]. The goal of the third step was to differentiate it from other sectors, and to find the features that distinguish it [24]. In the course of the research, being an exporter company was indicated as one of the strongest features characterizing the population of the HT group of companies. The fourth stage of the research was dedicated to exporters.

At this stage of the research, in addition to the sources of information previously used, a new source of data was used. The Analytical Centre of Customs Office (CAAC) has provided information on exporters among Warsaw companies in 2012. Nine new attributes supplied information about the range of export value, the main destination of exports, and the number and directions of export destinations. Moreover, with this information, it was possible to extract the companies that exported HT products, and to identify which part in their exports these products represented. The second round of screening of the companies' websites was undertaken in order to discover new features common to the analyzed population: HTME. The classification of attributes used in the study follows the structure shown in Table 2 .
With regard to export data obtained from CAAC, one of the attributes required additional explanation: EKSPORT_12, which provides additional information rather than only the range of the export value. The special value " $Z$ " indicates that a company exported goods during one or more of the years from 2008 to 2011, but it did not export any goods in 2012. In this case, the exporter was referred to as "inactive" and was not selected for further analysis. The other values of the attribute vary from " $\mathrm{A}$ " to "J," and refer to the company's export value in 2012. ${ }^{5}$ Detailed data are shown in Table 3.

In 2012, "micro exporters" exported up to 1 million PLN (ca. 240 thousand Euros); "small exporters," up to 8 million PLN (ca. 2 MEUR); "medium exporters" up to 64 million PLN (ca. 15,3 MEUR); and those referred to as "big exporters" exported above 64 million PLN. The highest "J" value indicates that the company exceeded 256 million PLN in exports in 2012 (ca. 61 MEUR).

The first step was to identify the HTME research group. The Warsaw population of 137 HTMs was compiled with the population of exporters $(16,241$ entities) operating in Warsaw as well. It appeared

\footnotetext{
${ }^{5}$ The average EUR exchange rate in 2012, according to the National Bank of Poland, was PLN 4,1850/EUR.
} 
that 110 of the 137 HT entities selected were amongst the companies that showed exports in the period considered. Among them, 61 (55\%) have a " $Z$ " value and have been considered as inactive exporters. The type of exported products in the remaining group of 49 companies has been verified and 12 of them did not export any HT products. Hence, the final number of firms that are both HT manufacturers and HT exporters has been identified as 37. This group of the selected 37 HTME comprises the subject of this study.

\section{Classification and segmentation characteristics of the HT population}

\section{Stage 1-2 of The Research Method}

The research undertaken in Stages 1 and 2 (Table 1) led to the development of characteristics of the Warsaw HT population. The results of this analysis is illustrated in Table 4.

Table 4. Results of distribution features characterizing the Warsaw HT enterprises population (source: authors' research)

\begin{tabular}{|c|c|c|c|}
\hline \multirow{2}{*}{ Attribute } & \multicolumn{3}{|c|}{ Distribution of attribute value } \\
\hline & Value & Quantity & $\%$ of population \\
\hline \multirow{3}{*}{ AKTYW } & 0 & 14 & 10,2 \\
\hline & 1 & 120 & 87,6 \\
\hline & None & 3 & 2,2 \\
\hline \multirow{3}{*}{ B2B } & 0 & 7 & 5,1 \\
\hline & 1 & 127 & 92,7 \\
\hline & None & 3 & 2,2 \\
\hline \multirow{3}{*}{$\mathrm{B} 2 \mathrm{C}$} & $\mathbf{0}$ & 89 & 65,0 \\
\hline & 1 & 45 & 32,8 \\
\hline & None & 3 & 2,2 \\
\hline \multirow{3}{*}{ CERT } & 0 & 51 & 37,2 \\
\hline & 1 & 83 & 60,6 \\
\hline & None & 3 & 2,2 \\
\hline \multirow{3}{*}{ EKSPORT } & 0 & 59 & 43,1 \\
\hline & 1 & 75 & 54,7 \\
\hline & None & 3 & 2,2 \\
\hline \multirow{5}{*}{ FP } & 16 Joint-stock company & 15 & 10,9 \\
\hline & 17 Limited liability company & 54 & 39,4 \\
\hline & 19 Civil law partnership & 10 & 7,3 \\
\hline & 99 One-man business & 49 & 35,8 \\
\hline & Other & 9 & 6,6 \\
\hline \multirow{6}{*}{ FW } & 214 Ownership of domestic physical persons & 95 & 69,3 \\
\hline & 215 Other private domestic ownership & 15 & 10,9 \\
\hline & 216 Foreign ownership & 7 & 5,1 \\
\hline & $\begin{array}{l}224 \text { Mixed ownership in private sector, with preva- } \\
\text { lence of ownership of domestic physical persons }\end{array}$ & 5 & 3,6 \\
\hline & $\begin{array}{l}226 \text { Mixed ownership in private sector, with preva- } \\
\text { lence of foreign ownership }\end{array}$ & 5 & 3,6 \\
\hline & Other & 10 & 7,3 \\
\hline
\end{tabular}


Table 4. Results of distribution features characterizing the Warsaw HT enterprises population, cont.

\begin{tabular}{|c|c|c|c|}
\hline \multirow{2}{*}{ Attribute } & \multicolumn{3}{|c|}{ Distribution of attribute value } \\
\hline & Value & Quantity & $\%$ of population \\
\hline \multirow{2}{*}{ FZ_1 } & $\mathbf{0}$ & 124 & 90,5 \\
\hline & 1 & 13 & 9,5 \\
\hline \multirow{8}{*}{ GD } & 038 Białołęka & 10 & 7,3 \\
\hline & 048 Bielany & 12 & 8,8 \\
\hline & 078 Praga-Południe & 12 & 8,8 \\
\hline & 138 Ursynów & 15 & 10,9 \\
\hline & 148 Wawer & 14 & 10,2 \\
\hline & 178 Włochy & 11 & 8,0 \\
\hline & 188 Wola & 15 & 10,9 \\
\hline & Other & 48 & 35,0 \\
\hline \multirow{6}{*}{ HiTech } & $\begin{array}{l}2120 \text { Manufacture of medicines } \\
\text { and other pharmaceutical products }\end{array}$ & 17 & 12,4 \\
\hline & 2611 Manufacture of electronic components & 17 & 12,4 \\
\hline & $\begin{array}{l}2620 \text { Manufacture of computers } \\
\text { and peripheral equipment }\end{array}$ & 16 & 11,7 \\
\hline & 2630 Manufacture of telecommunication equipment & 11 & 8,0 \\
\hline & \begin{tabular}{|l|}
2651 Manufacture of measuring, control \\
and navigational instruments and equipment
\end{tabular} & 35 & 25,5 \\
\hline & Other & 41 & 29,9 \\
\hline \multirow{3}{*}{ INNO } & 0 & 36 & 26,3 \\
\hline & 1 & 98 & 71,5 \\
\hline & None & 3 & 2,2 \\
\hline \multirow{3}{*}{ LANG } & 0 & 55 & 40,1 \\
\hline & 1 & 79 & 57,7 \\
\hline & None & 3 & 2,2 \\
\hline \multirow{3}{*}{ LPRAC } & 0-9 & 99 & 72,2 \\
\hline & $10-49$ & 19 & 13,9 \\
\hline & $50-$ & 19 & 13,9 \\
\hline \multirow{3}{*}{ NAUKA } & $\mathbf{0}$ & 94 & 68,6 \\
\hline & 1 & 40 & 29,2 \\
\hline & None & 3 & 2,2 \\
\hline \multirow{3}{*}{ PATENT } & $\mathbf{0}$ & 115 & 83,9 \\
\hline & 1 & 19 & 13,9 \\
\hline & None & 3 & 2,2 \\
\hline \multirow{3}{*}{ PRACOW } & 0 & 19 & 13,9 \\
\hline & 1 & 115 & 83,9 \\
\hline & None & 3 & 2,2 \\
\hline \multirow{3}{*}{ SOCIAL } & $\mathbf{0}$ & 127 & 92,7 \\
\hline & 1 & 7 & 5,1 \\
\hline & None & 3 & 2,2 \\
\hline
\end{tabular}


The most general description of the Warsaw HT companies is as follows:

- more than $75 \%$ of the sector comprises companies manufacturing electronic products $(77 \%)$, with the main groups including manufacture of measuring, control and navigational instruments and equipment,

- half of the sector $(50 \%)$ consists of commercial law companies (joint-stock companies or limited liability companies),

- micro-companies are dominating (up to $9 \mathrm{em}$ ployees),

- companies are located in the whole region of Warsaw, mainly in Ursynów, Wola, and Wawer,

- dominating ownership type is ownership of domestic natural persons; foreign capital share is limited and includes less than $10 \%$ of companies,

- the majority of companies are active on the Internet and maintain websites in foreign languages; however, they do not maintain any social networking service accounts,

- the majority of companies (72\%) describe themselves as innovative,

- companies strongly prefer B2B (business-tobusiness) than B2C (business-to-customer) type of sale,

- companies have certificates, but only $1 / 3$ of them cooperate with science centers and only few (14\%) have their own patents, and

- they are developing companies - active in exporting and recruitment of new employees searching for new employees.

\section{Stage 3 of The Research Method}

An in-depth analysis suggests that HT businesses differ from other companies with respect to the following features: conducting B2B activity, export activity, and searching for new employees. Certain ambiguity arose with respect to some activities related to science: cooperation with research centers, patents, and obtaining certification. On the one hand, these seem to be the most important features of HT companies; on the other hand, the number of companies that confirm that they conduct this type of activity is relatively low. To verify those assumptions, a segmentation analysis of the set was performed (Stage 3, Table 1) using two analytical methods:
(1) Ward's clustering method by means of which three segments were identified, and (2) Kohonen's self-organizing map (SOM) where four segments were identified. Segmentation carried out by these two different methods confirmed that there is considerable variation between the criteria distinguishing particular subgroups of entities within the HT population.

Segmentation by Ward's method produced a visible gradation of companies in terms of their export activity and scientific activity understood as: patenting, obtaining certification, and cooperation in the field of research (or running own laboratories). On the basis of this segmentation, two growth segments were distinguished: the exporting companies and the scientifically active companies (the segments differ in their level of development). The third segment includes companies that maintain their status quo rather than develop.

Using the self-organizing map, four segments were distinguished. This type of segmentation also distinguished between companies with a lower and a higher level of export and scientific activity. However, this description was enriched by adding new distinctive features. Thus, Segment 1a includes companies that are active in export and scientific research, but did not hold patents. Segment 3a, on the other hand, comprises companies that are active in export and hold patents. Segment 4a, whose characteristics are very similar to Segment 1a, has the biggest foreign capital share of all groups. Segment 2a, whose specification is similar to that of Segment 3a based on cluster analysis, does not compare favorably with other segments. It contains companies that currently do not have many features conducive to development. In summary of the obtained results, it should be concluded that the strongest criteria differentiating Warsaw HT companies are, in the order of importance:

- export activity,

- scientific activity, understood as: obtaining certification, cooperation with research centers (or running own laboratory), or holding patents,

- searching for and employing new workers,

- share of foreign capital in the form of ownership, and

- preference to B2B sale over B2C sale. 
Table 5. Characteristics of Segment 1a

(source: authors' research)

\begin{tabular}{|c|c|c|c|}
\hline \multirow{2}{*}{ Attribute } & \multicolumn{3}{|c|}{ Distribution of attribute value } \\
\cline { 2 - 4 } & Value & Quantity & \% of population \\
\hline \multirow{2}{*}{ EKSPORT } & $\mathbf{0}$ & $\mathbf{3}$ & $5,9 \%$ \\
\cline { 2 - 4 } & $\mathbf{1}$ & $\mathbf{4 8}$ & $\mathbf{9 4 , 1 \%}$ \\
\hline \multirow{2}{*}{ CERT } & 0 & 2 & $\mathbf{9 6 , 0 \%}$ \\
\hline \multirow{2}{*}{ LANG } & $\mathbf{1}$ & $\mathbf{4 9}$ & $5,9 \%$ \\
\hline \multirow{2}{*}{ NAUKA } & 0 & 3 & $\mathbf{9 4 , 1 \%}$ \\
\hline Zg_PKD & $\mathbf{1}$ & $\mathbf{4 8}$ & $43,1 \%$ \\
\hline
\end{tabular}

In addition, the segmentation of enriched data has made it possible to specify the characteristics of Segment 1a as follows (Table 5):

- having certificates (CERT = 1),

- cooperating with research centers $(\mathrm{NAUKA}=1)$,

- establishing websites in foreign languages $(\mathrm{LANG}=1)$, and

their activity is consistent with the declared PKD group $(\mathrm{Zg}$ _PKD $=1)$.

The segmentation of the enriched data showed the interesting group as a complete new one. This is a segment 5 of the characteristics indicate companies with great development potential (Table 6). They are usually limited liability companies $(\mathrm{FP}=17)$, and are characterized by:
- high level of hiring new employees (PRACOW $=1$ ),

- offering products and services in the B2B model $(\mathrm{B} 2 \mathrm{~B}=1)$,

- almost complete absence of the occurrence of the $\mathrm{B} 2 \mathrm{C}$ model $(\mathrm{B} 2 \mathrm{C}=0)$, and

- compatibility of business activities with the declared PKD group $(\mathrm{Zg}$ _PKD $=1)$.

In view of the obtained and confirmed analysis results, the research group for further analysis was selected. Taking into account the repeatability of the segmentation analysis results, the HT exporters group was indicated.

Table 6. Characteristics of Segment 5

(source: authors' research)

\begin{tabular}{|c|r|r|r|}
\hline \multirow{2}{*}{ Attribute } & \multicolumn{3}{|c|}{ Distribution of attribute value } \\
\cline { 2 - 4 } & Value & Quantity & \% of population \\
\hline B2B & $\mathbf{1}$ & $\mathbf{4 3}$ & $\mathbf{9 7 , 7 \%}$ \\
\hline B2C & $\mathbf{0}$ & $\mathbf{4 0}$ & $\mathbf{9 0 , 9 \%}$ \\
\hline B2C & 1 & 4 & $9,1 \%$ \\
\hline PRACOW & 0 & 3 & $6,8 \%$ \\
\hline PRACOW & $\mathbf{1}$ & $\mathbf{4 1}$ & $\mathbf{9 3 , 2 \%}$ \\
\hline FP & $\mathbf{1 7}$ & $\mathbf{3 2}$ & $\mathbf{7 2 , 7 \%}$ \\
\hline FP & $18,19,20,99$ & 10 & $27,3 \%$ \\
\hline Zg_PKD & 0 & 3 & $6,8 \%$ \\
\hline Zg_PKD & $\mathbf{1}$ & $\mathbf{4 1}$ & $\mathbf{9 3 , 2 \%}$ \\
\hline
\end{tabular}


5 Results of Stage 4 research HTE characteristic

Stage 4 of research method
The analysis of the HTME group will be divided into parts corresponding to the data sources. In Table 7, the results of the first part of the analysis, based on information from GUS and ZUS, are shown.

Table 7. Distribution of attributes characterizing HTME (within GUS/ZUS datasets) (source: authors' research)

\begin{tabular}{|c|c|c|c|}
\hline \multirow{2}{*}{$\begin{array}{l}\text { Attribute } \\
\text { Name }\end{array}$} & \multicolumn{3}{|l|}{ Distribution of value } \\
\hline & Value & Quantity & $\%$ of population \\
\hline \multirow{12}{*}{ HiTech } & 2110 manufacture of basis pharmaceutical substances & 3 & 8,1 \\
\hline & $\begin{array}{l}2120 \text { manufacture of medicines and other pharmaceutical } \\
\text { products }\end{array}$ & 5 & 13,5 \\
\hline & 2611 manufacture of electronic components & 4 & 10,8 \\
\hline & 2612 manufacture of electronic printed circuits & 2 & 5,4 \\
\hline & 2620 manufacture of computer and peripheral equipment & 5 & 13,5 \\
\hline & 2630 manufacture of telecommunication equipment & 3 & 8,1 \\
\hline & 2640 manufacture of consumer electronic equipment & 2 & 5,4 \\
\hline & $\begin{array}{l}2651 \text { manufacture of measuring control and navigational } \\
\text { instruments and equipment }\end{array}$ & 9 & 24,3 \\
\hline & $\begin{array}{l}2660 \text { manufacture of radiating equipment, electromedical and } \\
\text { electrotherapeutical equipment }\end{array}$ & 2 & 5,4 \\
\hline & $\begin{array}{l}2670 \text { manufacture of optical instruments and photographic } \\
\text { equipment }\end{array}$ & 2 & 5,4 \\
\hline & 2680 manufacture of unrecorded magnetic and optical media & 0 & 0 \\
\hline & $\begin{array}{l}3030 \text { manufacture of aircrafts, spacecraft, and similar ma- } \\
\text { chinery }\end{array}$ & 0 & 0 \\
\hline \multirow{5}{*}{ FP } & 16 joint-stock company & 10 & 27,0 \\
\hline & 17 limited liability company & 16 & 43,2 \\
\hline & 18 general partnership & 3 & 8,1 \\
\hline & 19 civil law partnership & 1 & 2,7 \\
\hline & 99 one-man business & 7 & 18,9 \\
\hline \multirow{2}{*}{ FZ_1 } & $\mathbf{0}$ & 34 & 91,9 \\
\hline & 1 & 3 & 8,1 \\
\hline \multirow{5}{*}{ LPRAC } & $0-9$ & 14 & $\mathbf{3 7 , 8}$ \\
\hline & $10-49$ & 11 & 29,7 \\
\hline & $50-249$ & 7 & 18,9 \\
\hline & 250-999 & 3 & 8,1 \\
\hline & $>999$ & 2 & 5,4 \\
\hline \multirow{2}{*}{ WA } & 0 & 0 & 0 \\
\hline & 1 & 37 & 100 \\
\hline
\end{tabular}


There are four types of businesses that dominate among the HTME entities: manufacturers of instruments and appliances for measuring, testing and navigation ( 9 entities); manufactures of computers and peripheral equipment; manufacturers of pharmaceutical preparations; and manufacturers of electronic components. This structure is similar to that of the HT manufacturers category, although it is worth noting the absence of aircraft and aerospace industries in the HTME group. As many as 26 out of 37 (70\%) HTME entities have chosen the legal form of a corporation (stock corp. or limited liability company), while in the HT group, this share is also high, but reaches only $50 \%$. Only three companies in the
HTME population have foreign equity participation (two pharmaceutical companies and one electronics manufacturer), which is similar to the entire group of HT also dominated by Polish capital.

Information about the size of employment in HTME indicates values greater than the average, but the data is not very reliable, because it refers to the situation at the time of company registration. All surveyed companies pay contributions to ZUS, which means that they are active and that they employ workers. In Table 8, the results of the second part of the analysis, which is based on information from the first screening of the companies' websites, are shown.

Table 8. Distribution of attributes characterizing HTME (within Website_1 datasets (source: author's research)

\begin{tabular}{|c|c|c|c|}
\hline \multirow{2}{*}{ Attribute Name } & \multicolumn{3}{|c|}{ Distribution of value } \\
\hline & Value & Quantity & \% of population \\
\hline \multirow{2}{*}{ AKTYW } & 0 & 0 & 0 \\
\hline & 1 & 37 & 100,0 \\
\hline \multirow{2}{*}{ B2B } & 0 & 0 & 0 \\
\hline & 1 & 37 & 100,0 \\
\hline \multirow{2}{*}{$\mathrm{B} 2 \mathrm{C}$} & $\mathbf{0}$ & 23 & 62,2 \\
\hline & 1 & 14 & 37,8 \\
\hline \multirow{2}{*}{ CERT } & 0 & 7 & 18,9 \\
\hline & 1 & 30 & 81,1 \\
\hline \multirow{2}{*}{ INNO } & 0 & 5 & 13,5 \\
\hline & 1 & 32 & 86,5 \\
\hline \multirow{2}{*}{ LANG } & 0 & 4 & 10,8 \\
\hline & 1 & 33 & 89,2 \\
\hline \multirow{2}{*}{ NAUKA } & 0 & 12 & 32,4 \\
\hline & 1 & 25 & 67,6 \\
\hline \multirow{2}{*}{ PATENT } & $\mathbf{0}$ & 30 & 81,1 \\
\hline & 1 & 7 & 18,9 \\
\hline \multirow{2}{*}{ PRACOW } & 0 & 1 & 2,7 \\
\hline & 1 & 36 & 97,3 \\
\hline \multirow{2}{*}{ SOCIAL } & $\mathbf{0}$ & 35 & 94,6 \\
\hline & 1 & 2 & 5,4 \\
\hline
\end{tabular}


All HTME companies have active websites and lead sales in the B2B model. Only in one case, the website is not clear that the company is looking for and employing new workers. The vast majority have certificates $(81.1 \%)$, define themselves as innovative $(86.5 \%)$, and also maintain a website in a foreign language (89.2\%).

The HTME companies outperformed the HT group in terms of holding patents and, remarkably, in cooperation with science. The share of firms holding patents has increased from 12\% (HT) to 19\% (HTME) and, from $27 \%$ (HT) to $70 \%$ (HTME) in the second discussed. It shows that cooperation with science defined as running a research laboratory, having an R\&D department, or hiring scientists - is an important distinctive factor for companies that build their competitive advantage in foreign markets. This kind of cooperation may be also related to the possession of certificates, which is attributed to $80 \%$ HTME (compared to $58 \%$ in the HT group).

A comparison of the HT and HTME groups in terms of attributes obtained from the first websites' screening is shown in Figure 1. It indicates better performance of HTME compared to HT group, which justifies further, in-depth studies of this subgroup.

In Table 9, the results of the third part of the analysis, based on exports information from the CAAC, are shown.

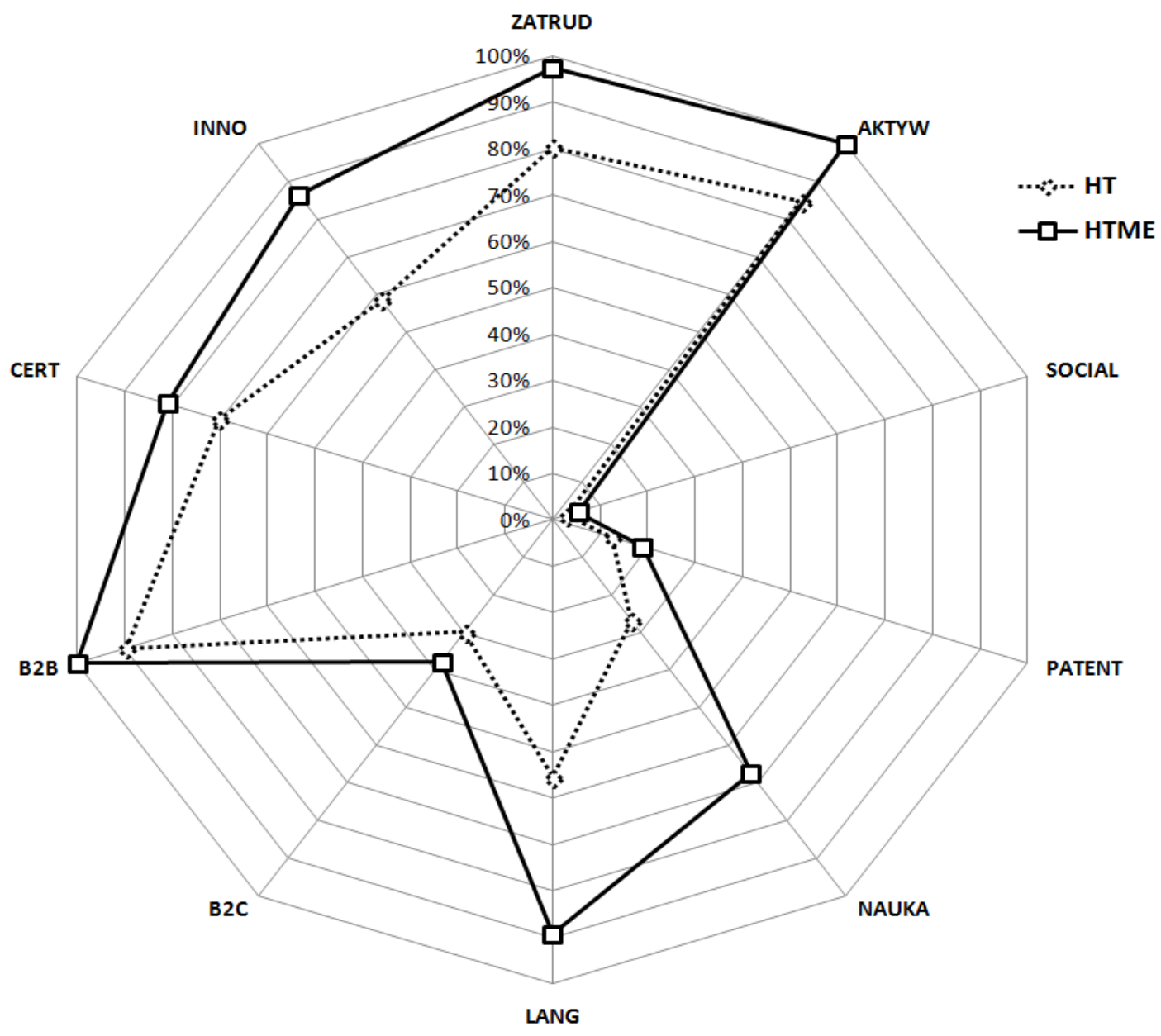

Figure 1. Comparison of HT and HTME groups based on attributes obtained from first websites' screening (source: authors' research) 
Table 9. Distribution of attributes characterizing HTME (CAAC datasets)

(source: authors' research)

\begin{tabular}{|c|c|c|c|}
\hline \multirow{2}{*}{ Attribute } & \multicolumn{3}{|c|}{ Distribution of value } \\
\hline & Value & Quantity & $\%$ of population \\
\hline \multirow{4}{*}{ EKSPORT12 } & $\mathbf{A}$ & 19 & 51,4 \\
\hline & $\mathrm{B}, \mathrm{C}, \mathrm{D}$ & 7 & 18,9 \\
\hline & $\mathrm{E}, \mathrm{F}, \mathrm{G}$ & 8 & 21,6 \\
\hline & $\mathrm{H}$ & 3 & 8,1 \\
\hline \multirow{7}{*}{ Eksporty_kraj } & Russia & 5 & 13,5 \\
\hline & Ukraine & 5 & 13,5 \\
\hline & Great Britain & 3 & 8,1 \\
\hline & USA & 3 & 8,1 \\
\hline & Germany & 2 & 5,4 \\
\hline & Lithuania & 2 & 5,4 \\
\hline & other ( 12 countries) & 1 each & $2,7(\mathrm{x} 17)$ \\
\hline \multirow{3}{*}{ E_Kraj/Exp \% } & $1-50$ & 16 & 43,2 \\
\hline & $51-99$ & 14 & 37,8 \\
\hline & 100 & 7 & 18,9 \\
\hline \multirow{3}{*}{ E_EU/E \% } & $\mathbf{0}$ & 22 & 59,5 \\
\hline & $1-50$ & 6 & 16,2 \\
\hline & $51-100$ & 9 & 24,3 \\
\hline \multirow{4}{*}{ Liczba_krajEU } & $\mathbf{0}$ & 22 & 59,5 \\
\hline & $1-10$ & 6 & 16,2 \\
\hline & $11-20$ & 8 & 21,6 \\
\hline & $>20$ & 1 & 2,7 \\
\hline \multirow{3}{*}{ Liczba_krajPOZA } & $1-10$ & 30 & 81,1 \\
\hline & $11-20$ & 4 & 10,8 \\
\hline & $>20$ & 3 & 8,1 \\
\hline \multirow{4}{*}{ Liczba_kraj } & 1 & 7 & 18,9 \\
\hline & 2-10 & 15 & 40,5 \\
\hline & $11-20$ & 8 & 21,6 \\
\hline & $>20$ & 7 & 18,9 \\
\hline \multirow{3}{*}{ grupaHT } & 1-aerospace & 1 & 2,7 \\
\hline & 2-computers & 2 & 5,4 \\
\hline & $\begin{array}{l}3 \text { - electronics - telecommunica- } \\
\text { tions }\end{array}$ & 13 & 35,1 \\
\hline
\end{tabular}


Table 9. Distribution of attributes characterizing HTME (CAAC datasets), cont.

\begin{tabular}{|l|l|c|c|}
\hline \multirow{2}{*}{ Attribute } & \multicolumn{3}{|c|}{ Distribution of value } \\
\cline { 2 - 4 } & \multicolumn{1}{|c|}{ Value } & Quantity & \% of population \\
\hline \multirow{5}{*}{ grupaHT } & $\mathbf{4}$ - pharmacy, & $\mathbf{8}$ & $\mathbf{2 1 , 6}$ \\
\cline { 2 - 4 } & $\mathbf{5}-$ scientific instruments & $\mathbf{1 0}$ & $\mathbf{2 7}$ \\
\cline { 2 - 4 } & 6- electrical machinery & 2 & 5,4 \\
\cline { 2 - 4 } & 7 -chemistry & 1 & 2,7 \\
\cline { 2 - 4 } & $8-$ non-electrical machinery & 0 & 0 \\
\cline { 2 - 4 } & $9-$ armament & 0 & 0 \\
\hline \multirow{5}{*}{ E_HT/E \% } & $<25$ & 3 & 27,0 \\
\cline { 2 - 4 } & $25-49$ & 1 & 2,1 \\
\cline { 2 - 4 } & $50-74$ & $\mathbf{2 3}$ & $\mathbf{6 2 , 2}$ \\
\cline { 2 - 4 } & $\mathbf{7 5}-\mathbf{1 0 0}$ & & \\
\hline
\end{tabular}

Among the HT products exported by HTME companies, four products clearly dominate with regard to distribution of value: electronics and telecommunications equipment, scientific instruments, and pharmaceuticals. With regard to the value of exports, the population has been divided evenly between exporters who sold goods abroad worth up to 1 million PLN in 2012 (19 companies) and those who exceeded this value (18 companies). No HTME company sold HT products for more than 128 million PLN.

The attribute "eksporty kraj" means a country in which the largest share of a company's exports is sold. During this research, 23 countries were identified, of which 4 countries were indicated by more than one firm. Results indicated Germany: 2 times, UK: 3 times, and Russia and the Ukraine: 5 times each. This means that in the HTME population there is a significant group of companies (10 entities), whose primary foreign trade partners are Russia or Ukraine. The other 10 entities indicated EU countries as the primary destinations for their exports. On the other hand, 22 companies $(60 \%)$ did not export to the EU at all.

With regard to the number of countries being export destinations, 22 companies exported to up to 10 countries, but the record holder showed as many as 57 countries as its export destinations (the company sells industrial measurement and control equipment).

The last indicator (E_HT/E \%) reflects the percentage of HT products in the total value of export. For 12 firms (1/3 of HTME), HT products represented $100 \%$ of the exports. For $2 / 3$ of them, HT products represented at least $50 \%$ of the export value.

While screening HTME websites, two additional attributes of the group were identified (Table 10). The first concerns the cooperation with science.

Table 10. Distribution of attributes characterizing HTME (within website_2study datasets)

(source: authors' research)

\begin{tabular}{|c|c|c|c|}
\hline \multirow{2}{*}{ Attribute } & \multicolumn{3}{|c|}{ Distribution of value } \\
\cline { 2 - 4 } & Value & Quantity & \% of population \\
\hline \multirow{2}{*}{ Research-oriented } & $\mathbf{1}$ & $\mathbf{2 2}$ & $\mathbf{5 9 , 5}$ \\
\cline { 2 - 4 } & 0 or ? & 15 & 40,5 \\
\hline \multirow{2}{*}{ Successor } & 1 & 9 & 24,3 \\
\cline { 2 - 4 } & $\mathbf{0}$ & $\mathbf{2 8}$ & $\mathbf{7 5 , 7}$ \\
\hline
\end{tabular}


The attribute "research-oriented" characterizes companies that were established based on scientific institutes cooperating with them, running their own scientific labs, or entities founded by (former) scientists.

The second attribute "Successor" characterizes entities that continue the tradition of the former state companies or institutions, established long before the Polish economy transformation in 1989. The analysis shows that the so-defined HTME subgroup is relatively significant and particularly interesting

The results of the last part of the study showed that $59 \%$ of HTME companies have close relationships with the world of science, and every fourth entity was founded on the basis of old state-owned enterprises or institutes

\section{Summary}

In this paper, two aims of the performed analysis were defined. Below are the most important conclusions and summaries

\section{O1: Preparation of the classification characteristics} of the Warsaw population of HTM companies.

To sum up the findings of the study, we can conclude that the HTMs based in Warsaw are mainly producers of electronic products and especially of measuring, control, and navigational instruments and equipment. In this group, the micro-companies are leading (up to 9 employees). They consist of commercial law companies (joint-stock companies or limited liability companies). The leading ownership type is the ownership of domestic natural persons. The majority of companies are active on the Internet and they maintain websites in foreign languages. However, they do not maintain any social networking service accounts. They describe themselves as innovative and strongly prefer B2B than B2C type of sale. Companies often have certificates but rarely cooperate with science centers and even more rarely have patents. Therefore, HTMs are developing by being active in export and searching for new employees

The characteristics of HTME subgroups are similar, but they enhance and highlight the most important features of the entire HT population. HTME manu- facturers are mainly producers of pharmaceuticals, electronics, and electronic components. They sell exclusively to other business entities (B2B type of transaction). Their legal status is more frequently corporate; their size is larger (in terms of employment). They show strong cooperation with science, including certificates or patent holdings. It is worth noting that their export destination to the East is more popular than to the West, and this tendency includes the highest value exports as well.

O2: To verify the hypothesis that export is strong and important distinguish criterion in the Warsaw population of manufacturing companies $H T$.

As shown in Figure 1, the HTME group strengthens the key values of the factors distinguishing the HT companies. These include such features as: having active websites in Polish and foreign languages, leading sales in the B2B model, looking for and employing new workers, having certificates, and being innovative. But most important is that the HTME companies outperformed the HT group in terms of holding patents and, remarkably, in cooperation with science. This shows that cooperation with science - defined as running a research laboratory, having an R\&D department, or hiring scientists - is an important distinctive factor for companies that build their competitive advantage in foreign markets. This kind of cooperation may be also related to the possession of certificates, which is much higher in the HTME than within the entire HT group. All of these features confirm the defined hypothesis.

Segment 1 was analyzed at Stage 4 of the research method. It was HTME group. There was omitted the second also highlighted segment 5 . Its characteristics include a high level of hiring new employees and offering products and services in the B2B model only. This is another interesting group that can be further researched in the HT population.

In order to confirm the observed insights and trends, it will be necessary to redo the analysis on updated data and make comparisons. Long-term conclusions could contribute to increased awareness about the Polish HT population, thereby increasing the effectiveness of methods dedicated for their development. 
[1] Bollinger L, Hope K., Utterback JM. - A review of literature and hypotheses on new technology based firms [in] Research Policy, Vol. 12, No. 1, 1983, pp. 1-14.

[2] Christensen C., Raynor M. - The Innovators Solution: Creating and Sustaining Successful Growth. Harvard Business School Press, Boston, 2003.

[3] Cieślik A., Michałek J.J., Michałek A. - Charakterystyki firm a ich zaangażowanie $w$ działalność eksportowq. Badanie dla krajów Europy Środkowo-Wschodniej [in] Zeszyty Naukowe Uniwersytetu Szczecińskiego. Wspótczesne Problemy Ekonomiczne, No. 8, 2014, pp. 31-41.

[4] Filatotchev I., Liu X., Buck T., Wright M. - The export orientation and export performance of high-technology SMEs in emerging markets: The effects of knowledge transfer by returnee entrepreneurs [in] Journal of International Business Studies, Vol. 40, No. 6, 2009, pp. 10051021.

[5] Francis J., Collins-Dodd C. - The impact of firms' export orientation on the export performance of high-tech small and medium-sized enterprises [in] Journal of International Marketing, Vol. 8, No. 3, 2000, pp. 84-103.

[6] Gierszewska G. - The Japanese Model of Knowledge Management [in] Foundations of Management, Vol. 4, No. 1, 2012, pp. 7-16.

[7] Goss E., Vozikis G.S. - High tech manufacturing: firm size, industry and population density [in] Small Business Economics, No. 6, 1994, pp. 291-297.

[8] Granstrand O. - Towards a theory of the technology-based firm [in[ Research Policy, Vol. 27, No. 5, 1998, pp. 465-489.

[9] Grinstein A, Goldman A. - Characterizing the technology firm: An exploratory study [in] Research Policy, Vol. 35, No. 1, 2006, pp. 121143.

[10] Hessels J., van Stel A. - Entrepreneurship, export orientation, and economic growth. Small Business Economics, Vol. 37, No. 2, 2011, pp. 255-268.

[11] Jaegers Th., Lipp-Lingua C., Amil D. - Hightechnology and medium-high technology industries main drivers of EU-27's industrial growth.
Industry, Trade and Services. Statistics in Focus, Eurostat, No. 1., 2013.

[12] Jovane F., Westkämper E., Williams D. - The Manu Future Road, Towards Competitive and Sustainable High-Adding-Value Manufacturing. Springer 2008.

[13] Kagermann H., Wahlster W., Helbig J. - Recommendations for implementing the strategic initiative Industrie 4.0. Technical Report. ACATECH - National Academy of Science and Engineering. 2013.

[14] Lasi H., Fettke P, Feld Th., Hoffmann M. - Application-Pull and Technology-Push as Driving Forces for the Fourth Industrial Revolution [in] Business \& Information Systems Engineering, Vol. 6, No.4, 2014, pp. 239-242.

[15] Malecki E.J. - Industrial location and corporate organization in high technology industries [in] Economic Geography, Vol. 61, No. 4, 1985, pp. 345-369.

[16] Matusiak K. - Wysoka Technika [in] Innowacje i transfer technologii. Stownik pojęć (ed. K. Matusiak), Wydanie III, PARP, Warszawa 2011.

[17] Mostafa R.H., Wheeler C., Jones M.V. - Entrepreneurial orientation, commitment to the Internet and export performance in small and medium sized exporting firms [in] Journal of International Entrepreneurship, Vol. 3, No. 4, 2005, pp. 291-302.

[18] Nelson A.J. - From the ivory tower to the startup garage: Organizational context and commercialization processes [in] Research Policy, Vol. 43, No. 7, 2014, pp. 1144-1156.

[19] Niedbalska G. - Pojęcie i klasyfikacja wyrobów wysokiej techniki [in] Ekonomika i Organizacja Przedsiębiorstwa, No. 10, 1999, pp. 3-7.

[20] O'Regan N., Sims M.A. - Identifying high technology small firms: A sectoral analysis [in] Technovation, Vol. 28, No. 7, 2008, pp. 408423.

[21] Oakey R. - High technology small firms: their potential for rapid industrial growth [in] International Small Business Journal, Vol. 9, No. 4, 1991, pp. 30-42.

[22] OECD - Classification of High-technology Products and Industries. DSTI/EAS/IND/STP (95)1, 1995.

[23] Rostek K., Skala A. - A profile of the hightechnology manufacturing sector in Warsaw [in] 
Shaping local business communities. The International Conference "Entrepreneurial Cities" Proceedings (eds. Koladkiewicz I., Cieślik J.) Stołeczne Forum Przedsiębiorczości, Akademia Leona Koźmińskiego, Warszawa, 2014a, pp. 3146.

[24] Rostek K., Skala A. - Differentiating criteria for high-tech companies [in] Management and Production Engineering Review, Vol. 5, No. 4, 2014b , pp. 46-52.

[25] Rostek K. - The Mutual Benchmarking Method for SMES' Competitive Strategy Development [in] Foundations of Management, Vol. 5, No. 2, 2013, pp. 81-96.

[26] Samson K.J., Gurdon M.A. - University scientists as entrepreneurs: a special case of technology transfer and high-tech venturing [in] Technovation, Vol. 13, No. 2, 1993, pp. 63-71.

[27] Skala A. - Nowa metoda identyfikacji przedsiębiorstw wysokiej technologii na przyktadzie Warszawy [in] Modern Management Review, Vol. XIX, No. 21(4/2014), 2014.

[28] Steenhuis H.J., de Bruijn E.J. - Technology geography: studying the relationships between technology, location and productivity [in] International Journal of Technology Transfer and
Commercialisation, Vol. 5, No. 3, 2006, pp. 195-207.

[29] Stuart T. - Interorganizational alliances and the performance of firms: a study of growth and innovation rates in a high-technology industry [in] Strategic Management Journal, Vol. 21, No. 8, 2000, pp. 791-811.

[30] Westhead P., Cowling M. - Employment change in independent owner-managed high-technology firms in Great Britain [in] Small Business Economics, 7(2), 1995, pp. 111-140.

[31] Westkämper E. - Towards the Re-industrialization of Europe: A Concept for Manufacturing for 2030. Springer Science \& Business, Berlin 2013.

[32] Zakrzewska-Bielawska A. - Relacje między strategia a strukturq organizacyjna $w$ przedsiębiorstwach sektora wysokich technologii [in] Zeszyty Naukowe nr 1095, Politechnika Łódzka, Łódź 2011.

[33] Zakrzewska-Bielawska A. - The strategic dilemmas of innovative enterprises: proposals for high-technology sectors [in] R\&D Management, Vol. 42, No. 4, 2012, pp. 303-314. 